\title{
Efficacy of Measuring Oxygen Extraction Ratio for Determination of Intraoperative Red Blood Cell Transfusion in a Case with Chronic Normovolemic Anemia
}

\author{
Yusuke Asakura*, Naoko Kato*, Yuko Sato* \\ Hiroshi Ito*, Yoshihiro Fujiwara*, Toru Komatsu*
}

\begin{abstract}
[Abstract] Allogeneic red blood cell transfusion should not be dictated, unless the patient's oxygen-carrying capacity is decompensated, and the signs and symptoms requiring blood transfusion have been observed. In cases with chronic normovolemic anemia, an increase of 2,3-DPG compensates the patient's oxygen delivery capacity by leading the hemoglobin-oxygen dissociation curve shift to right, thereby allowing the unloading of a normal oxygen amount with a lower concentration of hemoglobin, which makes it difficult to assess the appropriate timing for red blood cell transfusion. Here, we describe the efficacy of measuring the oxygen extraction ratio in such a case.

Key Words : Oxygen extraction ratio, Chronic normovolemic anemia, Red blood cell transfusion
\end{abstract}

(JJSCA Vol.26 No.7, $691 \sim 697,2006)$

\section{Introduction}

Theoretically, the only indication for allogeneic red blood cell transfusion is to increase the oxygen - carrying capacity ${ }^{1)}$. Red blood cell transfusion should not be dictated unless the patient's oxygencarrying capacity is otherwise decompensated and the signs and symptoms requiring blood transfusion have been observed ${ }^{2)}$. With respect to the appropriate timing for red blood cell transfusion, absolute hemoglobin or hematocrit values are of limited value in providing the basis for determining the requirements for red blood cell transfusion, due to the potential for extreme variation in each individual regarding their need for increased oxygencarrying capacity.

Oxygen transport and unloading at tissue level is regulated by the affinity of hemoglobin for oxygen, and this affinity is altered by several factors such as changes in the carbon dioxide tension $\left(\mathrm{PaCO}_{2}\right)$, $\mathrm{pH}$, temperature, and organ phosphates such as 2, 3-diphosphoglycerate (2,3-DPG) and adenosine triphosphate ${ }^{3)}$. The affinity of hemoglobin for oxygen is best described by the $\mathrm{PO}_{2}$ level at which

\footnotetext{
* Department of Anesthesiology,

Aichi Medical University,

Received Feb. 22, 2006

Nagoya, Japan 
hemoglobin is $50 \%$ saturated $\left(\mathrm{P}_{50}\right)$ on the oxyhemoglobin curve. The normal adult $\mathrm{P}_{50}$ value is $26.7 \mathrm{mmHg}$, and a $\mathrm{P}_{50}$ higher than $27 \mathrm{mmHg}$ describes a right-shifted oxy-hemoglobin curve, which means that at any given $\mathrm{PaO}_{2}$, hemoglobin has a low affinity for oxygen and is less saturated than normal, thus allowing a lower tissue perfusion than normal to produce the normal amount of oxygen unloading. Abnormalities in hemoglobin concentration also result in alteration of 2, 3-DPG metabolism to shift the oxy-hemoglobin curve, thereby allowing the unloading of normal oxygen amount with a lower concentration of hemoglobin. Thus, a patient with chronic normovolemic anemia may easily compensate for low concentrations of hemoglobin. In an attempt to elucidate the appropriate timing for red blood cell transfusion to transport appropriate oxygen to peripheral tissue in such a case, we found that measurement of the oxygen extraction ratio is efficacious in evaluating the requirements for red blood cell transfusion.

\section{Case Report}

A 53-year-old male, previously diagnosed with myasthenia gravis (MG) and who underwent thymo-thymomectomy 10 years ago, was admitted to our hospital because of shortness of breath and dyspnea. He showed no signs of muscle weakness, suggesting that the MG was in remission. His pleural biopsy showed a recurrence of invasive thymoma. On admission, his hemoglobin concentration was $7.9 \mathrm{~g} / \mathrm{dL}$ with an otherwise normal blood cell count profile, and bone marrow aspiration revealed severe erythroid hypoplasia. Accordingly, a diagnosis of pure red cell aplasia (PRCA) was made. Since his thymoma had diffusely disseminated in his left pleural cavity, he was scheduled for intrapleural perfusion hyperthermo-chemotherapy under video - assisted thoracoscopic surgery (VATS) ${ }^{4)}$.

After the induction of general and epidural anesthesia, radial arterial, central venous, and flowdirected pulmonary arterial (via the right internaljugular vein; Baxter Healthcare) catheters were inserted. Intra-arterial, central venous (CVP), pulmonary arterial (PAP), and pulmonary capillary wedge pressures (PCWP), heart rates, cardiac index $(\mathrm{CI})$, and mixed venous oxygen saturation $\left(\mathrm{S} \overline{\mathrm{v}} \mathrm{O}_{2}\right)$ were continuously monitored throughout the surgery. Stroke volume index (SVI), systemic vascular resistance index (SVRI), $\mathrm{TO}_{2}, \mathrm{VO}_{2}$, and $\mathrm{CaO}_{2}\left(\mathrm{TO}_{2}, \mathrm{VO}_{2}\right.$, and $\mathrm{CaO}_{2}$ indicate oxygen transport, oxygen consumption, and arterial oxygen content, respectively) were calculated by the standard formula as described in the previous report ${ }^{5}$. The electrocardiogram (ECG ; 5-lead) was monitored, and continuous ST-segment trend was analyzed during the surgery. An ischemic episode was defined as a reversible ST-segment shift from baseline of $0.1 \mathrm{mV}$ or greater depression at $\mathrm{J}+$ $60 \mathrm{msec}$, or $0.2 \mathrm{mV}$ or greater elevation at the $\mathrm{J}$ point lasting for at least 1 minute.

In the table, although his hemoglobin concentration was as low as $4.2 \mathrm{~g} / \mathrm{dL}$ with apparently lower values of $\mathrm{TO}_{2}$ and $\mathrm{VO}_{2}$ than normal individuals on the day of surgery, his oxygen delivery capacity was well preserved as demonstrated by the CI value of $2.4 \mathrm{~L} / \mathrm{min} / \mathrm{m}^{2}$, heart rate of 76 beats per minute, $\mathrm{S} \overline{\mathrm{v}} \mathrm{O}_{2}$ of $74 \%$, and 0.2 of $\mathrm{VO}_{2} / \mathrm{TO}_{2} \quad(20 \%$ of oxygen extraction ratio), suggesting that the compensation of oxygen delivery by the shift in the oxygen-hemoglobin dissociation curve had actually taken place. However, soon after intrapleural perfusion hyperthermo-chemotherapy was begun under the one-lung ventilation, SVRI and $\mathrm{S} \overline{\mathrm{v}} \mathrm{O}_{2}$ started to 
Table Peri-operative cardiopulmonary variables and oxygen-delivery profiles

\begin{tabular}{|c|c|c|c|}
\hline Variables & Pre-operative values & Just before the transfusion & Post-operative values \\
\hline SVRI (dyne $\left./ \mathrm{s} / \mathrm{cm}^{-5} / \mathrm{m}^{2}\right)$ & 1,736 & 1,034 & 1,383 \\
\hline Heart Rate (beats per minute) & 76 & 96 & 82 \\
\hline SVI $\left(\mathrm{mL} / \mathrm{m}^{2}\right)$ & 31.57 & 55.2 & 46.3 \\
\hline PVRI (dyne $\left./ \mathrm{s} / \mathrm{cm}^{-5} / \mathrm{m}^{2}\right)$ & 177 & 80 & 115 \\
\hline $\mathrm{Cl}\left(\mathrm{L} / \mathrm{min} / \mathrm{m}^{2}\right)$ & 2.4 & 5.3 & 3.8 \\
\hline $\mathrm{TO}_{2}(\mathrm{~mL} \mathrm{O} / 2 / \mathrm{kg} / \mathrm{min})$ & 5.13 & 10.8 & 9.02 \\
\hline $\mathrm{SvO} \mathrm{O}_{2}(\%)$ & 74 & 65 & 83 \\
\hline Arterial Blood pH & 7.479 & 7.454 & 7.396 \\
\hline Base Excess (mEq/L) & 0.4 & 0.5 & -4.3 \\
\hline $\mathrm{VO}_{2}(\mathrm{~mL} \mathrm{O} / \mathrm{kg} / \mathrm{min})$ & 1.04 & 3.29 & 1.31 \\
\hline $\mathrm{Hb}(\mathrm{g} / \mathrm{dL})$ & 4.2 & 4.4 & 5.2 \\
\hline Hematocrit (\%) & 12.3 & 13 & 15.9 \\
\hline $\mathrm{CVP}(\mathrm{mmHg})$ & 12 & $17^{*}$ & 13 \\
\hline $\operatorname{PAP}(\mathrm{mmHg})$ & 18 & $22 *$ & 16 \\
\hline PCWP $(\mathrm{mmHg})$ & 10 & $20^{*}$ & 12 \\
\hline $\mathrm{CaO}_{2}(\mathrm{~mL} / \mathrm{dL})$ & 7.113 & 6.83 & 7.886 \\
\hline $\mathrm{VO}_{2} / \mathrm{TO}_{2}$ & 0.2 & 0.3 & 0.14 \\
\hline
\end{tabular}

For abbreviations used in this table, refer to the text.

* These variables reflect the intrapleural direct pressure of hyperthermo-chemotherapy.

decrease, and his heart rate, SVI, and CI increased in response to the increase in $\mathrm{VO}_{2} / \mathrm{TO}_{2}$ ratio (oxygen extraction ratio), thereby compensating for the increased oxygen consumption under the status of decreased arterial oxygen content, which led us to start the 2 units of red blood cell transfusion, with the cutoff value of oxygen extraction ratio at approximately $30 \%$ and with a body temperature of $37.8^{\circ} \mathrm{C}$. No ST changes were observed in the monitored ECG. Two units of red blood cell transfusion totally resolved his observed inadequate oxygen delivery, with an $\mathrm{S} \bar{v} \mathrm{O}_{2}$ value of $83 \%$, which was even higher than the pre-operative value, and with an oxygen extraction ratio of $14 \%$, which was even lower than pre-operative value. Thus, we concluded that a hemoglobin concentration of $5.2 \mathrm{~g} / \mathrm{dL}$ was sufficient for adequate oxygen delivery.

\section{Discussion}

Despite the recommendations for red blood cell transfusion published to date ${ }^{6)}{ }^{7)}$, significant variances in transfusion practice persist between institutions. Although the incidence of transmission of diseases such as human immunodeficiency virus (HIV) and human hepatitis C virus (HCV) has become rare these days, serious complications related to red blood cell transfusion may still occur. The three most common causes of transfusionrelated deaths were hemolytic transfusion reactions, septic transfusions, and transfusion-related acute lung injury(TRALI) ${ }^{1)}$. From 1976 to 1985, 328 deaths related to transfusion have been registered with the US FDA (United States Food and Drug Administration), and 159 of these were from hemolytic reactions ${ }^{8)}$. Therefore, blood transfusions, 
like all the other medical treatments, should be prescribed only after consideration of the risks as well as the benefits of the therapy.

It is difficult to define the appropriate timing for red blood cell transfusion in a patient with chronic normovolemic anemia, because compensation for low hemoglobin concentration may occur. The problem of using an arbitrary hematocrit value for the initiation of red blood cell transfusion in such a case is that it does not take into account the individual patient's ability to compensate for anemia. For instance, young healthy individuals with normal cardio-respiratory function have been shown to easily compensate for acute isovolemic anemia with a hemoglobin value of $5.0 \mathrm{~g} / \mathrm{dL}^{5}$. On the contrary, a patient with a history of cardiovascular disease may easily reach his limits of compensation at a hemoglobin value of $5.0 \mathrm{~g} / \mathrm{dL}$.

In response to acute isovolemic anemia, which is often seen in the surgical setting, the cardiac output increases significantly, which involves both elevation of the heart rate and stroke volume accompanied by a decrease in systemic vascular resistance. All these responses compensate for the decreased arterial oxygen content, maintaining oxygen transport as hemoglobin concentration decreases ${ }^{5)}$. However, the magnitude of these responses may be substantially different depending on the individual patient's ability to compensate for anemia. On the contrary, the oxygen extraction ratio, which is the ratio of whole-body oxygen consumption to oxygen delivery, has been validated as an index of appropriate transfusion together with mixed venous oxygen tension ${ }^{9)}$. For instance, a previously healthy patient with postpartum bleeding has been reported to be stable at a hemoglobin concentration of as low as $1.7 \mathrm{~g} / \mathrm{dL}$ at an oxygen extraction ratio of approximately $40 \%$, while a 40 year-old traffic accident victim was hemodynamically unstable at a hemoglobin concentration of $3.0 \mathrm{~g} / \mathrm{dL}$ on nasal oxygen $\left(\mathrm{FiO}_{2} \mathrm{0.4}\right)$ with an oxygen extraction ratio of nearly $50 \%{ }^{9}$.

In the anesthetic management of the present case, we also found that the oxygen extraction ratio was quite efficacious in defining the appropriate timing for red blood cell transfusion. The cutoff value of the oxygen extraction ratio we utilized to start red blood cell transfusion in the present case was substantially lower than those described previously $^{9), 10)}$. We utilized a lower value in the present case, considering the effects of one-lung ventilation on arterial oxygenation. During one-lung ventilation, the non-dependent lung is not ventilated and any blood flow to the non-ventilated lung becomes shunt flow, in addition to whatever shunt flow might exist in the dependent lung. Thus, one-lung ventilation creates an obligatory right-to-left trans-pulmonary shunt through the non-ventilated non-dependent lung which is not present during dual-lung ventilation. Consequently, given the same inspired oxygen concentration $\left(\mathrm{FiO}_{2}\right)$ and hemodynamic and metabolic status, one-lung ventilation results in a much larger $\mathrm{P}_{\mathrm{A}} \mathrm{O}_{2}-\mathrm{PaO}_{2}$ gradient and a lower $\mathrm{PaO}_{2}$ than dual-lung ventilation does.

One major drawback in utilizing this variable is the use of a pulmonary artery catheter. In view of the outcome of patients who were critically ill, pulmonary artery catheterization has evoked some controversy. The first and most provocative argument arose from the article written by Connors et al. ${ }^{11)}$, followed by the randomized controlled trial of the use of a pulmonary artery catheter in highrisk surgical patients, which concluded that there 
had been no benefit to pulmonary artery catheterization over standard care in the elderly and/or high-risk surgical patients ${ }^{12)}$. Accordingly, practice guidelines that indicate the appropriate use of pulmonary artery catheters have been published ${ }^{13), 14)}$. As the guidelines indicate, apparently the routine use of pulmonary artery catheter in any surgical, or non-surgical setting should be avoided due to the potential risks. However, in certain cases and settings, the benefits may outweigh those risks. Aside from its pressure-monitoring capabilities, the most important feature of the pulmonary artery catheter is its ability to measure cardiac output by the thermodilution method, which virtually enables evaluation, in any given circumstance, of the oxygen supply-and-demand balance in the body including the oxygen extraction ratio.

To the extent that arterial hemoglobin saturation, cardiac output, and oxygen consumption remain stable, mixed venous oxygen tension may also be used as an indicator of the adequacy of hemoglobin concentration and may provide comprehensive information on the adequacy of the oxygen delivery and consumption balance in the body. However, although the normal value of mixed venous oxygen tension is well known, the appropriate therapeutic target value for each individual patient remains uncertain to date. By contrast, recent reports suggest that a 40-45\% oxygen extraction ratio is a feasible value for when to start red blood cell transfusion, and $50 \%$ as close to the critical level where oxygen delivery fails to satisfy the oxygen demand in peripheral tissue in a case with acute isovolemic anemia ${ }^{9)}$.

Theoretically, tragic deaths may be easily avoided by continuous monitoring of the oxygen extraction ratio, and by alerting surgeons to the status of the oxygen delivery-demand balance in the body before reaching that critical level where oxygen delivery fails to satisfy its demand in peripheral tissue, for instance, in the surgical setting with patients who refuse blood transfusion for religious reasons or with those who suffer from hemolysis due to unexpected antibodies.

In summary, we report here the efficacy of measuring the oxygen extraction ratio in the anesthetic management of a case with chronic normovolemic anemia. Measurement of the oxygen extraction ratio is beneficial to patients undergoing elective surgery who refuse blood transfusion for religious reasons or to those who suffer from a shortage of donor blood. It also may ultimately help to reduce blood transfusions, thereby reducing the incidence of the transmission of blood-borne diseases and blood transfusion-related deaths.

Acknowledgements: The first two authors listed contributed equally to this report and should be considered co-first authors. We thank Ms. Keiko Kubota for her secretarial assistance, and Drs. Yasuyuki Shibata, Shuji Kurokawa, Yoshiko Wakao, and Masayo Matsuura for their helpful advice. This report was presented in part at the $25^{\text {th }}$ Congress of Japan Society for Clinical Anesthesia.

\section{References}

1) Miller RD : Transfusion therapy, Miller's Anesthesia. Edited by Miller RD. Churchill Livingstone, Philadelphia, 2005, 1799-1830

2) American College of Physicians: Practice strategies for elective red blood cell transfusion. Ann Intern Med 116 : 403-406, 1992

3) Piccioni MA, Cestari IA, Strunz CM, et al. : Decreased 2, 3-diphosphoglycerate concentration in low cardiac 
output patients and its influence on the determination of in vivo $\mathrm{P}_{50}$. Artif Organs 27 : 676-680, 2003

4) Watanabe S, Sakasegawa K, Shimokawa S, et al. : Intrapleural perfusion hyperthermo-chemotherapy under video-assisted thoracoscopic surgery for malignant pleural dissemination: a case report. Anticancer Res 22 : 3781-3783, 2002

5) Weiskopf RB, Viele MK, Feiner J, et al. : Human cardiovascular and metabolic response to acute, severe isovolemic anemia. JAMA 279: 217-221, 1998

6) Office of Medical Applications of Research, National Institutes of Health: Consensus conference. Perioperative red blood cell transfusion. JAMA 260: 27002703, 1988

7) ASA Task Force: Practice guidelines for blood component therapy: A report by the ASA Task Force on Blood Component Therapy. Anesthesiology 84 : 732747, 1996

8) Gibble JW, Ness PM : Fibrin glue : the perfect operative sealant? Transfusion $30: 741-747,1990$

9) Sehgal LR, Zebala LP, Takagi I, et al. : Evaluation of oxygen extraction ratio as a physiologic transfusion trigger in coronary artery bypass graft surgery patients. Transfusion $41: 591-595,2001$
10) Wilkerson DK, Rosen AL, Gould SA, et al. : Oxygen extraction ratio : a valid indicator of myocardial metabolism in anemia. J Surg Res 42 : 629-634, 1987

11) Connors AF Jr, Speroff T, Dawson NV, et al. : The effectiveness of right heart catheterization in the initial care of critically ill patients. SUPPORT Investigators. JAMA $276: 889-897,1996$

12) Sandham JD, Hull RD, Brant RF, et al. : A randomized, controlled trial of the use of pulmonary-artery catheters in high-risk surgical patients. N Engl J Med $348: 5-14,2003$

13) ASA Task Force : Practice guidelines for pulmonary artery catheterization : an updated report by the American Society of Anesthesiologists Task Force on Pulmonary Artery Catheterization. Anesthesiology 99 : 988-1014, 2003

14) American College of Physicians/American College of Cardiology/American Heart Association Task Force on Clinical Privileges in Cardiology : Clinical competence in hemodynamic monitoring. A statement for physicians from the ACP/ACC/AHA Task Force on Clinical Privileges in Cardiology. J Am Coll Cardiol 15 : 1460-1464, 1990 


\title{
慢性貧血患者での術中の赤血球輸血開始の指標としての 酸素摂取率測定の有用性
}

\author{
朝倉雄介 加藤尚子 佐藤祐子 \\ 伊藤 洋 藤原祥裕 小松 徹 \\ 愛知医科大学麻醉科学講座
}

赤芽球疼を合併した播種性再発胸腺腫の麻酔管理を通じ oxygen extraction ratio (OER ; 酸素摂取率) が赤血球輸血開始の有用な指標となると思われた手術麻酔症例を経験したので報告する，症例は 53 歳， 男性. 再発胸腺腫胸腔内播種に対し胸腔内温熱化学療法が施行された. 患者は赤芽球疼を合併しており, 手術室入室時の $\mathrm{Hb}$ は $4.2 \mathrm{~g} / \mathrm{dL}$ であったが，同時に測定された心係数は $2.4 \mathrm{~L} / \mathrm{min} / \mathrm{m}^{2}$ ，混合静脈血酸素飽 和度は $74 \%$ ，酸素摂取率は $20 \%$ であり，慢性貧血による代償機転が働いていると判断されたため赤血 球輸血は施行せず手術開始となった。手術進行とともに心係数は $5.3 \mathrm{~L} / \mathrm{min} / \mathrm{m}^{2}$ に上昇, 混合静脈血酸素 飽和度は $65 \%$ に低下，酸素摂取率は $30 \%$ に上昇した。代謝が低下している全身麻酔中でのこれらの値 の変化は覚醒させた際に代謝が上昇すると耐容能を超える可能性が予測されたため, 2 単位の赤血球輸 血を行ったところ， $\mathrm{Hb}$ は $5.2 \mathrm{~g} / \mathrm{dL}$ であったが，心係数は $3.8 \mathrm{~L} / \mathrm{min} / \mathrm{m}^{2}$ に低下し，混合静脈血酸素飽和度 は $83 \%$ に改善, 酸素摂取率は $14 \%$ まで低下し, それ以上の赤血球輸血を必要とすることなく手術終了 とともに手術室にて抜管することが可能であった。赤血球輸血の厳密な適応は障害された酸素運搬能の 改善にあり，失われた循環血液量の補正のために赤血球輸血が施行されることは容認されない. 酸素運 搬能の障害の度合いに対しての耐容能が個々の患者により大きく異なるため，Hbや Htのみで赤血球輸

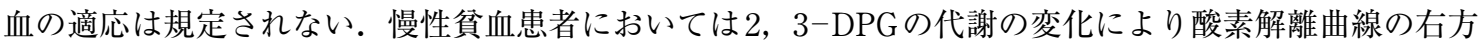
シフトが生じ，通常の急性貧血よりも貧血に対する耐容能が高くなることが予測されるが，このような 症例に扔ける赤血球輸血開始の指標は現在まで明確に示されていない，過去の急性貧血における報告で はOERとして 40〜 45\%が輸血開始として適正な指標となり，50\%が耐容能の限界に近いとの報告もあ る. 待機手術でのエホバの証人の手術麻酔時や，不規則抗体を多くもつために輸血血液の供給に問題が ある症例などにOERをモニタリングすることにより OERが $40 \%$ 超えた場合，手術を一時中断しても らうことなどにより生命に危機的な状況を回避できる可能性がある．今後さらにその有用性を積極的に 評価，検討していくべきであると思われた.

Key Words : Oxygen extraction ratio, 慢性貧血, 赤血球輸血

The Journal of Japan Society for Clinical Anesthesia Vol.26 No.7, 2006

本症例報告は，読みやすく，教育的価值の高い論文であるが，読者であるわれわれに 以下のような問題を提起している.

1. Oxygen extraction ratio 指標として赤血球輸血を開始することの是非.

2. 赤芽球病を合併しているとはいえ, $\mathrm{Hb} 4.2 \mathrm{~g} / \mathrm{dL}$ で手術を開始することの是非.

本症例報告を読んで, 上記の点に関しなんらかのご意見 (当然, 賛成意見も歓迎です) をお持ちの先生方は，本誌「コラム」欄にご意見をお寄せください.

日本臨床麻醉学会誌編集刊行委員会

委員長 大下修造 